\title{
Prevalence of HIV-I drug resistance mutations in antiretroviral naïve pregnant women from Cambodia, Cameroon, Central African Republic and Vietnam
}

\author{
Ahidjo Ayouba*1, Lénaig Le Fouler², Truong TX Lien³, Nary Ly', \\ Valérie Maréchal ${ }^{5}$, Aurélia Véssière ${ }^{1}$, Anfumbom Kfutwah ${ }^{1}$, Jean \\ Marc Reynes ${ }^{4}$, Elisabeth Menu ${ }^{6}$, Eric Nerrienet ${ }^{1}$, Muriel Vray ${ }^{2}$, Hervé Fleury ${ }^{7}$ \\ and Françoise Barré-Sinoussi ${ }^{6}$
}

\begin{abstract}
Address: ${ }^{1}$ Virology laboratory, Centre Pasteur du Cameroun, Yaoundé, Cameroon, ${ }^{2}$ Unité d'épidémiologie des maladies émergentes, Institut Pasteur, Paris, France, ${ }^{3}$ Virology Laboratory, Institut Pasteur, Ho Chi Minh Ville, Vietnam, ${ }^{4}$ Laboratory of HIV and Hepatitis, Institut Pasteur, Pnom Penh, Cambodia, 5 Virology Laboratory, Institut Pasteur, Bangui, Central African Republic, ${ }^{6}$ Unité de Régulation des Infections Rétrovirales, Institut Pasteur, Paris, France and 7Virology Laboratory, Université Bordeaux 2, Bordeaux, France

* Corresponding author
\end{abstract}

from Fourth Dominique Dormont International Conference. Host-Pathogen Interactions in Chronic Infections

Paris, France. 13-15 December 2007

Published: 9 April 2008

Retrovirology 2008, 5(Suppl I):OI8 doi:I0.II86/I742-4690-5-SI-OI8

This abstract is available from: http://www.retrovirology.com/content/5/SI/OI8

(c) 2008 Ayouba et al.; licensee BioMed Central Ltd.

\section{Background}

Since 2003 seven laboratories of the International Network of Pasteur Institutes have implemented HIV-1 genotypic drug resistance tools. These tools were then applied to study primary antiretroviral (ARV) resistance in drugnaïve HIV positive pregnant women living in central Africa (Cameroon, Central African Republic or CAR) and South-East Asia (Cambodia, Vietnam).

\section{Methods}

HIV-1 positive ARV naïve pregnant women who gave their written informed consent participated to the study. In addition to clinical examination, EDTA blood samples were collected for T-CD4 count, plasma HIV-RNA viral load determination and ARV genotypic resistance testing following the French ANRS AC11 guidelines for both reverse transcriptase and protease genes. HIV genetic sequences were analysed with the latest version of the ANRS, Stanford HIVdb and IAS algorithms. HIV-1 subtypes were determined by phylogenetic analysis and BLAST search. Statistical comparisons of the results were performed through the Fisher's exact test or Kruskall-wallis test, whenever appropriated.

\section{Results}

Overall, 362 women participated: 95 in Cameroon, 93 in CAR, 122 in Cambodia, and 52 in Vietnam. At inclusion, the median age was 26 years (IQR:22-30). For most of the women $(94 \%)$, HIV status was known for less than a year and 31\% were in their first pregnancy. The median CD4 counts was 358 cells/mm3 (IQR: 220-551). The median HIV-RNA viral load was 4.6 Log RNA copies/ml (IQR: 4$5)$ in Cameroon and CAR.

Phylogenetic analysis revealed that $96 \%$ and $98 \%$ of viral sequences from Cambodia and Vietnam, respectively, belonged to the CRF01_AE subtype. In Cameroon, $60 \%$ of the samples clustered with CRF02_AG subtype, but 10 other subtypes were encountered. In CAR, $40 \%$ and $22 \%$ of samples belonged to CRF11 and A1 subtypes respectively. Seven strains of 362, 1.9\%, (4 from Cambodia, 2 from Vietnam and 1 from Cameroon) harboured mutations associated to major ARV resistance in RT gene: 4 with V75M (resistance to D4T), 1 with the K101E (resistant to NVP and EFV) and the last one with the mutation L210W/T215S (weak resistance to AZT/D4T). In the protease gene, 3 strains ( 1 from Cameroon and 2 from Cam- 
bodia) bore N88 alone or associated to M46I, conferring resistance to IDV and NFV.

\section{Conclusion}

This four-sites study confirmed the high genetic diversity of HIV-1 circulating in Central Africa compared to the hegemony of CRF01_AE in South-East Asia. Drug resistance mutation survey revealed prevalence below $5 \%$ in this sentinel population, consistent with the recent introduction of ARV in these countries.

\section{Acknowledgements}

This work is presented on behalf of the FSP/RAI/ARV Study Team.

Publish with Bio Med Central and every scientist can read your work free of charge

"BioMed Central will be the most significant development for disseminating the results of biomedical research in our lifetime. " Sir Paul Nurse, Cancer Research UK

Your research papers will be:

- available free of charge to the entire biomedical community

- peer reviewed and published immediately upon acceptance

- cited in PubMed and archived on PubMed Central

- yours - you keep the copyright 